\title{
'Fishing after News' and the Ars Apodemica: The Intelligencing Role of the Educational Traveller in the Late Sixteenth Century
}

\author{
Elizabeth Williamson
}

The subject of this chapter is the sending of news and information from English travellers abroad to the governing circles of late Elizabethan England. A stay abroad carried with it an expectation that casual travellers, to protect and evidence their moral, spiritual and physical health, would make themselves useful, and thus loyal, servants of their domestic government: I will argue that one key method of doing so was by transmitting news and information. Immediately, this invites questions regarding what and who exactly is being discussed. Although I will not fully explore here the complexities of what is meant by 'news', 'knowledge' and (political) 'intelligence', rough distinctions between these terms are implicated in the primary focus of this chapter. These distinctions and the associations they carry bear directly on how we and contemporaries regard the individual who gathers information. This is because the intention and motivation for travel define and justify the traveller: the inflection of their information-gathering activity matters. ${ }^{1}$ The crux is that there is an indistinctness surrounding who the traveller is and what they are travelling for; a blurred status or lack of definition that means that the traveller provides a valuable opportunity for access (to news, to people, to places), but also that they are at risk of suspicion and the accusation of immorality, whether they present as the nobleman or gentleman, the ambitious scholar or the employed agent, the youth or the tutor. I would argue that this ambiguity pivots on the kind of information the individual is expected or is seen to gather: in reductive terms, whether it is perceived as defensible learning, infective intelligence or common news.

In an activity where even the humanist traveller or the accredited diplomat could be branded with 'the hellish Judas name of an Intelligencer', role, intention and perception are as important as action. ${ }^{2}$

1 That this can be difficult to ascertain, uncertain or obscured, both then and now, does not negate the point.

2 Thomas Nashe, Have With you to Saffron-Walden. Or, Gabriell Harveys hunt is up Containing a full answere to the eldest sonne of the halter-maker. Or, Nashe his confutation of the sinfull

(C) ELIZABETH WILLIAMSON, 2016 | DOI 10.1163/9789004277199_024

This is an open access chapter distributed under the terms of the Creative Commons Attribution-

Noncommercial-NoDerivatives 3.o Unported (CC-BY-NC-ND 3.o) License 
To begin with the contemporary literature, the many didactic treatises in the humanist tradition of the ars apodemica - a genre that grew rapidly in popularity in the late sixteenth century-all lay emphasis on travel's educative function, and on how knowledge gained by it should be put towards the good of the common weal. Beyond the rhetoric, however, travel could be about more than civic or humanistic virtue and self-improvement; the traveller could be a valuable node in the news-gathering network, able to send information back to patrons or potential patrons in domestic government. The literary tradition is composed of original, copied and circulated manuscript letters and, from the 1570s, of printed pamphlets, essays and treatises offering travel advice and guidance, adjoined to which is a counter-current of warning and chastisement by critics including Roger Ascham, Joseph Hall and Richard Mulcaster. ${ }^{3}$ There is a self-conscious balance maintained in travel advice texts between practical dealing and moral display; a focus on method, on civic duty, and on absorbing and recording information, employing a rhetoric of usefulness for both individual and state that acts as a counter to the critics of leisurely travelling for its own sake. I contend that this more moral and literary edge to the genre can mask - or protect - travellers' involvement in news and intelligence gathering.

William Bourne's A booke called the Treasure for Traueilers (1578) is one of the first printed expressions in English of the humanist ideal of aiding the country through self-development as a reason for travel:

they are very necessary members in the common weale in divers respectes, that are travaylers into other Countries, and they are able to profyt theyr owne Countrie in divers respectes: for that hee is able to geve judgement by his owne Countrie of other, whether it bee as touching the governement of the common weale, in the executing of their lawes of the manner of traffick, and in the usage and nature of the people, bothe

doctor (London, 1596), sig. Q3v, USTC 513218. The subject of the line, ambassador to the Low Countries Thomas Bodley, is comically defended against this accusation, and so insulted in the process.

3 See Roger Ascham, The scholemaster or plaine and perfite way of teaching children, to understand, write, and speake, the Latin tong but specially purposed for the private bringing up of youth in jentlemen and noble mens houses, and commodious also for all such, as have forgot the Latin tonge (London, 1570), and Richard Mulcaster, Positions wherin those primitive circumstances be examined, which are necessarie for the training up of children either for skill in their booke, or health in their bodie (London, 1581), USTC 507247 and 509387. In the seventeenth century, Bishop Joseph Hall is another vocal critic, from a strongly anti-Catholic perspective. For literature relating to a later proto-Grand Tour tradition, see Andrew Hadfield, Literature, Travel, and Colonial Writing in the English Renaissance, 1545-1625 (Oxford: Oxford University Press, 1998). 
in their Cities and Townes, and in their Countrie, and what manner of commodities they have, and of the situation of their Townes, and in their fortifycation, and also of what strength and force other Princes and states are of, and of the order and manner of usyng them selves in martial affayres in the warres, and what their Artillerie is, and how they are weaponed and armed, and furnished in every respect ... for that they may provide them selves, and their Countrie for their better safetie ... ${ }^{4}$

This introduces a common reason for and recommended style of knowledge gathering: the only way to truly comprehend (and appreciate) one's own country is by comparing it to others. A lengthy enumeration of what to observe, covering topographical, anthropological, legal, financial, mercantile and military matters, is typical of the ars apodemica and is repeated time and time again. Yet this list, heavily weighted towards matters of defence, suggests the collection of information of a much more practical value than that cultivated solely for personal enlightenment. Before the emergence of regular newspapers, and with a geographically and financially limited diplomatic network, letters from travellers in the right place at the right time conveying information of the kinds listed above would be a valuable resource for those constructing foreign policy.

For people of both higher and more middling status, travel was increasingly seen as preparatory for crown service. For those in need of external support, perhaps second sons or ambitious gentlemen, it could be a way to demonstrate skills and please patrons, and in the literature is often directly framed as a method by which to gain employment in the work of state, on the level of clerkships, secretaryships or diplomatic appointments. Thomas Palmer gives an overview of the subject in The Travailer, or An essay of the meanes how to make our travailes, into forraine countries, the more profitable and honourable, printed in $1606 .{ }^{5}$ Details on the subjects listed by the ars apodemica, Palmer says,

are the utensils, and materialls of States men, concerning forraine matters: the which many active mindes though sitting at home are well read in: and except it bee for the secrets and other occurrences, alterations \&

4 William Bourne, A booke called the Treasure for Traveilers, devided into five Bookes or partes, contayning very necessary matters, for all sortes of Travailers, eyther by Sea or by Lande, written by William Bourne (London, 1578), USTC 508489, sig. **iiir-v; see also Sara Warneke, Images of the Educational Traveller in Early Modern England (Leiden: Brill, 1995), p. 45.

5 Thomas Palmer, The Travailer, or An essay of the meanes how to make our travailes, into forraine countries, the more profitable and honourable (London, 1606). 
changes, the difference is not much betweene the home States man, not having spent some time in travaile, \& the compleate Travailer, for forraine matters. ${ }^{6}$

Accordingly, some of the kind of information they are expected to gather can also be gained by reading; this knowledge of foreign lands is the material of government, and also relates travel to the kinds of research skills (of the assimilation and presentation of information) that are frequently emphasised as preparatory for the work of government. The particular advantage of the traveller is their access to "secrets and other occurrences, alterations \& changes". Essentially, the difference is first-hand, updated information on recent happenings: news, in other words.

Palmer's is an important distinction, and a clue as to the various kinds of information people could gather, which in turn speaks to a potential linguistic difference between information and intelligence, and perhaps between intelligence and news. Information and knowledge are associated with scholarship and learning, and stable fact. Intelligence and news contain more of a sense of updated, event-based, and privileged information to which not everyone has access, and which, being liable to change, can thus be false. There is anxiety here: intelligence and news require the individual to be at less of a remove from the world than the relatively safer activities of reading and scholarship; they risk involvement with the wrong kind of people, with gossip and with rumour. Information one sees oneself is the freshest and least adulterated kind, but it is also that which most implicates the individual: personal agency is foregrounded, which both risks moral health and, depending on the level of trust already enjoyed, could lead either to reportage being valued as uncontaminated or questioned as uncorroborated. Palmer elaborates on the positives of the traveller's personal access: "herein hath a Travailer the start of a home States man, which is fed by advertisements only, and is ledde by other mens eyes". 8 The traveller has the advantage of undiluted experience-direct sight-and as well as the (supposed) increased accuracy of that which is seen and heard over that which is read, the traveller is consequently able to 'feed' and thus 'lead' the statesman himself. He can turn his experience into advertisement: he can make news. As well as that of travel providing training for future government service, Palmer articulates a key reason for travel as

6 Palmer, The Travailer, sig. H3r.

7 Palmer, The Travailer, sig. H3r.

8 Palmer, The Travailer, sig. H3r. 
providing an opportunity to attract new patrons or please existing ones with the delivery of news - exhibiting as well as refining these skills of information assimilation and presentation. Palmer directly instructs the traveller and would-be crown servant to secure themselves future preferment by "advertising, from time to time by Letters during their travaile, some one of the privie Councell, and none other of the Countrie to which they belong, of such occurrences and things as chance worthie to be sent and committed to consultation and viewe". 9

Instruction by a printed pamphlet and direct invitation by a figure at court are obviously and importantly different matters. One can question whether such bonding and preferment would have worked in reality, outside of conduct books, especially if unsolicited and especially as the genre became more widespread in print. Though there is explicit encouragement to gather news in Palmer, such texts (particularly circulated manuscript letters) also had the very real rhetorical function of defending the morality of travel and thus of the traveller. Further, the instruction they provided on method and knowledge of foreign lands could be seen as being applicable to stationary scholarship as well as to educational wandering: after all, much information on a country could also be gained by reading. One has to be aware therefore that travel advice texts do not necessarily require one to travel.

However, the literary and academic context does not mean that these texts were not also read as practical instruction, and as well as printed pamphlets, manuscript letters of advice were sent and used. By the late sixteenth century, sending and copying 'heads' of information detailing what to gather to best please one's contacts or sponsors was a secure epistolary genre, with wellknown letters circulating in manuscript. Many of the earliest surviving letters of this kind are from prominent statesmen and privy councillors, revealing an origin in practical politics, before the tradition became established and spread into the realm of print. Some of those still extant include William Cecil, Lord Burghley writing to the third earl of Rutland, to Lord Zouche, and to his own sons Thomas and Robert; Secretary of State Francis Walsingham to an unnamed nephew; and later Robert Devereux, earl of Essex to the fifth earl of Rutland and to many others of a less exalted status. ${ }^{10}$ Such texts can inhabit several

9 Palmer, The Travailer, sig. R4r.

10 William Cecil, Lord Burghley to Edward Manners, third earl of Rutland, 20 January 1571: Warneke, Educational Traveller, Appendix B, pp. 295-8; TNA, SP 12/77/10. Burghley to Edward la Zouche, eleventh Baron Zouche, 1587: mentioned in Warneke, Educational Traveller, p. 47 n.26; Bodleian Library, Tanner 103/230-2. Burghley to Thomas Cecil, 1561: 'A Memorial for Thomas Cecil' in Louis Wright, Advice to a Son: Precepts of Lord 
contexts: either they are read and copied as literary prose, attracting interest by their substance and style, or as pieces of advice to be applied and followed. ${ }^{11}$ Some letters present themselves as more one than the other; for example, in the trio of advice letters from Essex to Roger Manners, fifth earl of Rutland, one letter's focus is clearly oratorical display, and it is accordingly circulated widely as political propaganda, whereas the third letter is written very differently and is much more practical and direct in style, composed of a central paragraph

Burghley, Sir Walter Raleigh, and Francis Osborne (New York: Cornell University Press, 1962). Walsingham to an unnamed nephew, undated but suggested by Conyers Read to have been written during Walsingham's secretaryship, so between 1573-90: Conyers Read, Mr Secretary Walsingham and the Policy of Queen Elizabeth, 3 vols. (Oxford: Clarendon Press, 1925), 1: 18-20. Robert Devereux, earl of Essex to Roger Manners, fifth earl of Rutland, printed as 4 January 1596: Robert Devereux et al., Profitable instructions describing what speciall observations are to be taken by travellers in all nations, states and countries; pleasant and profitable. By the three much admired, Robert, late Earle of Essex. Sir Philip Sidney. And, Secretary Davison (London, 1633), pp. 27-73, sigs. C6r-2Ar; see also Paul Hammer, 'Letters of Travel Advice from the Earl of Essex to the Earl of Rutland: Some Comments', Philological Quarterly, 74:3 (1995), pp. 320-1 for a discussion of these letters and their dating. Another letter giving advice on his travels was apparently sent from Burghley to Edward Manners, dated 2 March 1570/1, though it is possible that this is the date of reception of the earlier letter: The Manuscripts of his Grace the Duke of Rutland, G.C.B., Preserved at Belvoir Castle, 4 vols., HMC, Twelfth Report, Appendix IV (London: HMSO, 1888), 1: 91. Additionally, a letter from Edward's uncle, Roger Manners (not the recipient of Essex's letters), reassures Edward that he is doing well and should continue as he is, and that 'Lord Sussex and Lord Burghley will, as occasion serves, send you their opinions', 4 July 1571, Rutland MSS, 1: 94. This shows that advisory letters could continue beyond an initial, more formulaic letter on the ars apodemica seen above.

There are many examples of re-copying and re-using travel advice letters, sometimes in different contexts. An example can be found in the multiple extant copies of the advisory text written for the young Francis Davison by his father, offering advice in bracketed diagrams, akin to Ramist tables of dichotomies (a popular format). As well as being printed in Benjamin Fisher's 1633 Profitable Instructions, referenced above, copies include an undated manuscript titled "Most brief but excellent Instructions for a Traveller written by Secretary Davison for His Son", and "Short instructions for a Traveller", the latter of which shows evidence of some kind of practical use, with tears and discolouration, and several different fold marks and multiple creases in a pattern that suggests folding and re-folding into a small packet (BL Harley Ms 6893, fos. 169r$72 \mathrm{v}$, at fo. $169 \mathrm{gr}$, and Harley MS 252, fo. $123 \mathrm{r}-\mathrm{v}$, respectively). A wholly different use is seen in the similar copy BL Harley MS 1579 , fos. $86 \mathrm{r}-96 \mathrm{r}$, which is copied directly into a large volume as a polished exposition of political history and logical form, and so likely not meant to advise during travel. 
giving an extensive list of what to observe in terms of geography, man-made features (fortification, navy, ports) and mode of governance. ${ }^{12}$

There is an overlap between these active and academic uses, as they are not mutually exclusive. The more famous letters to well-known figures are more likely to survive and circulate, but this bias does not mean that the tradition is limited to these single instances. As well as occasional reference to other letters between less exalted figures, there is a strong tradition of re-use and copying, and of course one does not need to be sent a letter by the secretary of state in order to be aware of the expectations and opportunities of travel. ${ }^{13}$ Indeed, Essex's oratorical 'first' letter to Rutland, though itself a political exercise, spreads the idea of an openness to the transmission of news:

I Hold it for a principle in the course of Intelligence of State, not to discourage men of meane capacity from writing unto mee; though I had at that same time very able aduertisements: for either they sent mee matter which the other omitted, or made it clearer by describing the circumstances, or, if added nothing, yet they confirmed that which comming single I might have doubted. ${ }^{14}$

Though this largesse is to be taken with a hefty pinch of salt, such an invitation would clearly appeal to clients and would-be clients-the wording is even referenced directly in a letter by Essex's secretary as justification for his

12 Indeed, Paul Hammer contends that the 'first' Essex-Rutland letter was never sent to Rutland, but rather was inspired by the three that were sent, and written purely as political self-positioning. The 'first' letter is either therefore missing or is this widely-circulated letter, the second letter is missing but referred to, and the third letter is printed in full in The Manuscripts of the Duke of Beaufort, K.G., the Earl of Donoughmore, and Others, HмC, Twelfth Report, Appendix Ix (London: HMso, 1891), pp. 172-3, and survives in only two manuscript copies.

13 For another less high-powered example, consider Walsingham's communication with William Stonehouse: Elizabeth Williamson, 'Before "Diplomacy": Travel, Embassy and the Production of Political Information in the Later Sixteenth Century', PhD thesis (Queen Mary University of London, 2012), pp. 38-9. As another example of a copied letter, consider the letter from Philip Sidney to his brother Robert, copied into traveller Stephen Powle's commonplace book, who travelled with Robert for a time in the 1580 s and became a client of William Cecil, delivering news and scholarly information. See Williamson, 'Before "Diplomacy"', pp. 53, 55-6. I am grateful to Nicholas Popper for sharing unpublished work on Stephen Powle. 
transmitting of news from the court at Greenwich..$^{15}$ The claim also suggests something of Essex's current practice regarding news and intelligence: though it is unlikely that he would encourage unfettered communication, it does suggest the plurality of his sources of information, and so how the aforementioned anxious uncertainty of news could be mitigated.

An active epistolary relationship provides evidence that a news-gathering traveller could have a real audience, and so I will now discuss some instances of this kind of communication and exchange. The types of relationships reflected or called into being by such letters-or by the naturalisation of an expectation of news-gathering into the social understanding of the activity of travel—could be between clients and patrons, between those seeking and proffering monetary reward or future preferment, or between people of more equal standing. One important aspect affecting the role of the traveller and how they were perceived was their social status. The earls of Rutland provide several examples of young noblemen going abroad for this kind of educative travel, receiving such letters of advice and sending news and information back in their correspondence. Edward Manners, the third earl of Rutland and the recipient of a letter of travel advice from Lord Burghley in 1571, was 21 years old on his departure for France, his nephew Roger who received the aforementioned advice letters from Essex was just 19 years old, and Francis, younger brother to Roger, was about 20 when he toured France, Italy and the Empire. ${ }^{16}$

On first glance, the 1571 letter of advice from Burghley to Edward Manners appears to recommend a personal journal for recording information: he should "make a booke of paper, wherin [he] may dayly or at the lest wekely insert, all thyngs occurrant to [him]". ${ }^{17}$ Though Burghley states that Rutland is not bound

15 "Once again I crave pardon for trobling your lordship with many triviall advertisements. I follow herein your owne precept to the noble earle of Rutland, not to defer any man from writing in this kind, bycause it doth at the least confirme that which yow receave from others" Lambeth Palace Library, Ms 657, fo. 108v. Edward Reynoldes to Robert Devereux, May 1596. Quoted in Hammer, 'Essex to Rutland', 324, n. 21. See also Thomas Birch, Memoirs of the Reign of Queen Elizabeth, from the Yeare 1581 till Her death, 2 vols. (London, 1754), 1: 478.

16 Of these three, Francis was the only one to make significant headway in the world of politics after his travels, becoming a privy councillor. Both Roger and Edward seem to have been more focused on their country estates, with Edward plagued by ill health and Roger tarnished by his involvement in the Essex uprising. It should also be stressed that relative youth does not need to mean inexperience; Edward Manners had already served the crown against the northern insurgents in 1569 , before travelling in 1571 . See respective entries in the $O D N B$.

Warneke, Educational Traveller, p. 295. 
to deliver such an account to anyone else, this is not to say that the letter does not encourage the transmission of information. Burghley carefully enumerates key aspects to observe over several pages, with particular focus on political and military matters, including instruction to determine "Who ar the principall officers of the realmes". ${ }^{18}$ Sara Warneke points out that Burghley sent a very similarly worded letter to Lord Zouche before his travel on the continent in 1587 , suggesting that these are not isolated examples. ${ }^{19}$ Later that month Rutland drafted a letter of "News from France", including the names of principal officers in Picardy and sketched plans of two forts. ${ }^{20}$ He sends Burghley several letters, and repeatedly asks for further advice, indicating that he is keen to act as a loyal servant of the crown. ${ }^{21}$ Though in one letter he references a "want of occurants", Rutland goes on to detail information on current happenings in France, including mention of a "slaughter" at Rouen and its effect on Protestants, the reception of English travellers, and an account of the coronation of Elisabeth of Austria, complete with a list of the "principall and only officers that did attend". ${ }^{22} \mathrm{He}$ sends this news despite stating that "this matter wilbe larglyer \& planer written unto $\mathrm{y}^{\mathrm{u}}$ ", as an explanation as to why he is " $\mathrm{y}^{\mathrm{e}}$ brefer" in his report: he transmits news without positioning himself as a key news-gatherer or (heaven forbid) intelligencer. ${ }^{23}$ In this high-status relationship, the news exchange and requests flow both ways, since after conveying information on France Rutland discusses his domestic concerns, namely the selling of his woods in Walthamstow, and asks that Burghley take an interest and write letters of support if necessary. In one sense he is seen responding to Burghley's letter of advice, gathering news and information, but he hints at returning home and asks how to do so without offence: he recognises that he is

18 Warneke, Educational Traveller, p. 298.

19 Warneke, Educational Traveller, p. 47, n. 26. The original manuscript is in the Bodleian, Tanner MS 103/230-2.

20 "News from France. 1571, January 31 to February.-Notes taken by the Earl of Rutland on his journey from Calais to Amiens, giving the names of the principal officers in Picardy, and rough plans of two forts", Rutland MSs, 1: 91.

21 For example, see the letter dated 28 April 1571, Rutland to Burghley, on response in Paris to the taking of Dumbarton, Rutland MSs, 1: 92; and also TNA, SP 70/118, fo. 89r.

Rutland to Burghley, March 1571, TNA, SP 70/117 fo. 55r. Elisabeth, Archduchess of Austria, married Charles IX of France in November 1570. Her coronation was on 25 March 1571. The massacre is likely the "massacre of Bondeville" on 18 March 1571, a riot that resulted in the deaths of 40 protestants. See Philip Benedict, Rouen During the Wars of Religion (Cambridge: Cambridge University Press, 2004), p. 121.

23 SP $70 / 117$ fo. 55 r. 
obligated in his travels, but more by duty and fear of mis-stepping than by the promise of future patronage or employment.

Often, however, the traveller is more directly bound, and enters into a more transactional relationship with their correspondents: this, in particular, is where greyer areas and greater anxieties creep into the construction of travel and the role of the traveller. There is much to be gained by productive travel, and as further gains are sought more risk-reputational, moral and even physical-may come into play. The further along this road one goes, the more one intersects and overlaps with the world of diplomacy and intelligence gathering. University education, legal training, and foreign travel appear again and again in the biographies of diplomats, clerks and councillors in Elizabethan politics: travel is part of both the training expected and the activity undertaken once a position is attained, and can be a stepping stone to salaried crown service. The status and degree of official commission held by a diplomatic agent can itself be vague or contentious, and, particularly when the figure is some variety of crown agent rather than a resident ambassador, I would argue that we can better understand early modern diplomacy by considering activities undertaken rather than focussing solely on fixed roles and named appointments. In this construction of diplomacy, there is not much to distinguish the traveller from the agent or intelligencer if they supply the same functions, such as gathering news and synthesising intelligence, liaising with useful people, bearing letters and so on. An example can be seen in Henry Wotton's offerings to Lord Zouche when travelling in Europe in the 1590s, about which Lisa Jardine and William Sherman observe "[t]his kind of 'intelligence' plainly embraces both sensitive and innocuous, scholarly and political knowledge, and elides the functions of information gatherer and spy". ${ }^{24}$ The enhanced intelligence service that the traveller Wotton offers aims at mitigating the recognised fact that he is in competition with others who vie to attract attention with news; he therefore suggests that he couple his "plain kind of service" (i.e. the delivery of news), with a scholarly service, that is, the active gathering and synthesis of in-depth knowledge and the procurement of books and manuscripts, to attempt to secure Zouche's patronage and a more involved relationship. ${ }^{25}$

24 Lisa Jardine and William Sherman, 'Pragmatic Readers: Knowledge Transactions and Scholarly Services in late Elizabethan England' in Religion, Culture and Society in Early Modern Britain (Cambridge: Cambridge University Press, 1994), pp. 102-24, at 105.

25 Wotton travelled through Europe for five years from 1589, and at the time he contacted Zouche had procured lodgings with the imperial librarian, Hugo Blotius. He seems to have secured books for Zouche, though his primary patron was later to be none other 
Patronage could mean explicit or implicit sponsoring of travel, or it could give a specific role or task to the traveller; obligation could be invoked by assistance in obtaining a passport, by a letter of travel advice, by direct instruction, or by money, but whichever the context there is always an expected return, and for the traveller it is always information (in one form or another). Even if not framed as a directly transactional relationship, there is an ever-present sense of due return in letters of advice, to be discharged in the dutiful action of gathering information, and this obligation is generated in the first instance by the letter itself and secondarily by the frequent implication of future career assistance, and in some cases strengthened by the enclosure or mention of a monetary gift. ${ }^{26}$ This is the case in a letter of travel advice of uncertain attribution, either from Thomas Bodley to Francis Bacon or from Fulke Greville to a younger relation. ${ }^{27}$ After obligatory reference to previous correspondence, the printed versions of the letter open with an unceremonious and almost apologetic reference to monies sent: "I have sent you by your Merchant for your present supply zoli, and had sent you a greater summe, but that my extraordinary charges this yeere have utterly unfurnished me". ${ }^{28}$ That this mention of money is present in the printed Greville version accords with the fact that he is seen elsewhere actively sponsoring travellers, such as John Coke, for whom he provided as much as £200 per annum and a commission to travel for three years on behalf of the earl of Essex in order to "report to Greville and Essex on matters

than that key patron of travel and intellectual service, the earl of Essex. See Jardine and Sherman, 'Pragmatic Readers'.

26 The subject of money is referred to several times in Philip Sidney's letters to his brother Robert, see Steuart Pears, The Correspondence of Sir Philip Sidney and Hubert Languet (Farnborough: Gregg International Publishers, 1971), pp. 223-4.

27 Letter of travel advice, from Bodley to Bacon: The Life of James Usher, Late Lord Archbishop of Armagh ... With a Collection of Three Hundred Letters (London, 1686), p. 17, Letter XIII; from Greville to his nephew Varney: Certaine Learned and Elegant Workes of the Right Honourable Fulke, Lord Brooke (London, 1633), p. 295. For discussion of the authorship claims, see Elizabeth Williamson, 'A letter of travel advice? Literary rhetoric, scholarly counsel and practical instruction in the ars apodemica', in Lives and Letters, 3:1 (2011), <http://journal.xmera.org/journalarchive/Williamson.pdf>[03/03/16], and The Oxford Francis Bacon, 1: Early Writings 1584-1596, ed. Alan Stewart with Harriet Knight (Oxford: Oxford University Press, 2012), Appendix C. With thanks to Alan Stewart for allowing me to view the unpublished manuscript.

28 The Life of James Usher, p. 17; Workes, Lord Brooke, p. 295. The version printed in the 1633 Workes, Lord Brooke does not include the '3oli', but leaves a lacuna. Manuscript and print versions of the letter as attributed to Greville variously include the 3 oli or a lacuna. 
of interest to the English government". ${ }^{29}$ The Bodley/Greville letter links financial contribution to a due return, but this is an indirect nudge rather than an explicit demand. By insisting that he "will be no severe exactor of account, either of your money or time", the writer affirms by negation that he does indeed expect repayment of a kind, passively reminding the reader that both his money and time are indebted. ${ }^{30}$ While he adheres to the tradition of warning the young traveller to protect his moral virtue and learn all he can, a key function of the letter is detailing the type of information the sender would like relayed. This may, the writer states, "make your life more profitable to your country, and yourself more comfortable to your friends", which again employs indirect language to couple the dual motivations of information gatheringpatriotism and personal advancement. ${ }^{31}$ His closing comments seal the deal more overtly, and stress in a friendly but firm tone the expected response:

If in this time of your liberal traffic, you will give me any advertisement of your commodities in these kinds, I will make you as liberal a return from myself and your friends here, as I shall be able. ${ }^{32}$

We can see that within the courtly advice there is practical dealing, where talk of "advertisement" harkens back to the Palmer treatise, and the terms of the trade- - commodities" and "return" - are set out.

This rhetoric blurs what is sought after- the letter appears to request information, listing ad nauseam what to gather, yet it states that the writer's "purpose is not to bring all your observation to heads". ${ }^{33}$ It stresses that, being in France, he must learn of "the Ordinances, Strength, and Progres of each [i.e. Huguenot and Catholic], in Reputation, and Party, and how both are supported, balanced and managed by the State", while warning against spending all his time "like an Intelligencer, in fishing after the present News, Humours, Graces or Disgraces of court". ${ }^{34}$ Again, this divergence is in part a rhetorical function to protect against the immorality of travel, and in part because the

29 See Ronald Rebholz, The Life of Fulke Greville, First Lord Brooke (Oxford: Clarendon Press, 1971), p. 96.

30 Reliquiae Bodleianae: Or some Genuine Remains of Sir Thomas Bodley. Containing his Life, the first Draught of the Statutes of the Publick Library at Oxford, (in English) and a Collection of Letters to Dr James \&c. (London, 1706), p. 364.

$31 \quad$ Reliquiae Bodleianae, p. 369.

32 Reliquiae Bodleianae, p. 369.

33 Reliquiae Bodleianae, p. 368.

34 Reliquiae Bodleianae, pp. 365, 367. 
prioritisation of scholarship over gossip, and of knowledge over news, was considered valid. There is a thirst for both reliable news and more digested accounts (especially of the political situation), but an anxiety over anything potentially immoral or risky. Alongside the Polonius-style rhetoric, one finds advice to gather military and/or secret information, such as when Essex suggests that Rutland get assistance uncovering matters that are "martiall, and others points of State", and advice by Palmer to buy and even bribe when necessary; "to procure with their purse, what by discretion, observation, and friends, cannot be attained unto". ${ }^{35}$ Much of this advice does therefore appear to encourage "fishing after News". ${ }^{36}$ There is a conflict between what is stated and what is implied here and elsewhere, and room for individuals to slip between the gap, and into perhaps unanticipated expectations. This can be seen in further examples of the various men who travelled under the advice, assistance or influence of the earl of Essex.

Essex involved himself heavily in foreign intelligencing activities, building an intelligence network of his own to transmit information from the continent, which incorporated both independent travellers and employed agents. ${ }^{37}$ The distinction as well as the proximity between different types of traveller and agent emerges in Paul Hammer's discussion of the interaction between Henry Hawkins, Essex's agent in a "semi-official English diplomatic and intelligence-gathering station in Venice", and Francis Davison, the young traveller more indirectly encouraged by Essex, and who was sent a letter of travel advice by his father. ${ }^{38}$ Both men's travels were "largely facilitated and paid for by Essex", and both appeared in Venice at the same time, prompting a clash between them that points to an overlap in their activity and its desired results, with Hawkins viewing Davison "as a potential competitor for the Earl's favour". ${ }^{39}$ Despite this, their circumstances were different and the line between the two men can be seen as being grounded in the control and the notion of overt employment, which is implicitly recognised in Hammer's differentiation: "Essex's hunger for knowledge and belief in the educative effects of European

35 Palmer, The Travailer, p. 127.

$36 \quad$ Reliquiae Bodleianae, p. 367.

37 See especially Paul Hammer, 'The Use of Scholarship: The Secretariat of Robert Devereux, Second Earl of Essex, c. 1585-1601', The English Historical Review, 109 [430] (1994), pp. 26-51; "Essex sought to buttress his claims to be a budding statesman by cultivating a leading role in diplomacy and the gathering of foreign intelligence", p. 30 .

38 Hammer, Paul, 'Essex and Europe: Evidence from Confidential Instructions by the Earl of Essex 1595-6', The English Historical Review, 111 [441] (1996), pp. 357-81, at 362.

Hammer, 'Essex and Europe', p. 364. 
travel apparently extended to the encouragement of gentleman travellers, as well as the employment of salaried agents". ${ }^{40}$ These are subtle but important distinctions that define Hawkins as Essex's diplomatic agent and client, and Davison first and foremost as an educational traveller but one owing a return on the earl's investment, and who, though not explicitly employed, is still instructed in the form of gentlemanly advice both from his father and from Essex himself. ${ }^{41}$ Unfortunately, Davison's travel was not considered a great success: he ran into debt with expensive living and was criticised by his father, though he did send a treatise on Saxony to Essex through Anthony Bacon. ${ }^{42}$

Sliding even more finely between the examples of Davison and Hawkins is Robert Naunton, a scholar who approached Essex for assistance in obtaining a travel licence for his own educational tour in 1595, but who ended up being transformed from a sponsored and guided but essentially independent traveller into a paid agent. Essex decided that instead of undertaking his own expedition, Naunton should become a mediator between the earl and Antonio Perez in France. ${ }^{43}$ That the situation was not Naunton's preferred outcome is evident from a letter two years into his travel, clearly illustrating his dilemma of wanting unrestricted travel and freedom to pursue the self-improvement of the ars apodemica but being inextricably bound to Essex's command:

I desire to goe hence \& be no more seen here. But whether to goe, I dare not desire of myse[lf] without $\mathrm{yo}^{\mathrm{r}} \mathrm{Lp}$ approbacion ... $\mathrm{Y}^{\mathrm{r}} \mathrm{Lps}$ former directions have so inured $\mathrm{m}[\mathrm{e}]$ as I cannot now promise myselfe in any sort to improv[e] my travail without $\mathrm{y}^{\mathrm{r}} \mathrm{Lp}$ priscription \& allowance of my

$40 \quad$ Hammer, 'Essex and Europe', p. 364.

41 Devereux, Profitable Instructions, pp. 1-24. See Hammer for evidence that Essex sent Davison a letter of advice, 'Essex and Europe', p. 364, n. 4.

42 See John Considine, 'Davison, Francis (1573/4-1613x19)', ODNB, <www.oxforddnb.com/ view/article/7300> [29/06/14].

43 See Hammer, 'Essex and Europe', pp. 365-6. See also Gustav Ungerer, A Spaniard in Elizabethan England: the Correspondence of Antonio Pérez's Exile (London:Tamesis Books, 1975-6), vol. 2, for transcripts of several of Naunton's letters during this time, esp. p. 97 for Essex promising further employment for Naunton once these duties with Perez have been dispatched. A letter of 20 January 1597 (n.s.) from Naunton to Essex sees him thanking Essex for obtaining his passport, and giving an account of being back in England with Perez in April-May 1586. In it, he states that he was unable to bow completely to Perez' wishes since they conflicted with his duty owed to Essex; "my devotion to himself had deflected me thus farre out of my course entred as to return with him thither at his spetiall instance for the time of his employment, yet I might not so abuse her $\mathrm{Ma}^{\text {ts }} \& \mathrm{yo}^{\mathrm{r}}$ Lops favoures as not to employ my time as I had pretended to yow" (2: 109). 
course ... I am ashamed of myselfe to thinck how farre I have strayed from the first intent \& drift of my travaile, which was only to have prepared \& inhabled myselfe so as I might have done yo ${ }^{\mathrm{r}}$ Lps service at my returne. ${ }^{44}$

Naunton manifests the distinction between traveller and commissioned agent when he became wholly subject to Essex and his commands in his travels. As part of his new role as agent mediating with Perez, Naunton was also clearly expected to keep Essex updated with the latest news and reports on the political climate. In a long letter detailing current political affairs in France, Naunton opens by stressing how much he has already been writing to Essex. ${ }^{45} \mathrm{He}$ states that "Though I have wrote soe much allreddie in $\operatorname{div}^{\mathrm{r}} \mathrm{s}$ of my last letters, \& specallye in my last of the 7 hereof", he is duty-bound to write again on the same matter, "to adv ${ }^{r}$ tise all the allteracions \& motives $y^{t}$ fall out here touching that affaire". 46 That this letter of news is of value to the governing circles is demonstrated by the fact that it survives as a contemporary copy in the Harley collection of the British Library, and also because one of its readers has underlined sentences of particular importance.

There is considerable overlap between the categories of employment, sponsorship, patronage and friendship, and these ambiguities oblige educational travellers to attend carefully to how they place and conduct themselves. The situation is doubly problematic because the attributes that could be used now to identify someone as a diplomatic or intelligencing agent-clear instructions, direct pay or subsequent recompense - may not actually exist, even if the individual self-identified as such. Additionally, as Robyn Adams points out, there is a very blurred line between a private and a crown intelligencer. ${ }^{47}$ The guise under which one travels can be confused and unclear to contemporaries, and even to the travellers themselves, as with the frustrated Naunton. One might be nearer to being an agent than a client, a diplomat than an intelligencer, or actually be employed in crown service already but travelling seemingly without specific commission. This latter appears to be Henry Cheke's case, an Elizabethan gentleman who involved himself in transmitting news whilst travelling. Cheke was well connected by family, but needed an income

44 Robert Naunton to Essex, Paris, 10 December 1597 (n.s.), Ungerer, Antonio Perez, pp. 144-5.

45 'Copie of a Letter from Mr Robert Naunton', BL Harley MS 288, fos. $245 \mathrm{r}-8 \mathrm{v}$.

46 BL Harley MS 288, fo. 245 r.

47 See Robyn Adams, 'A Most Secret Service: William Herle and the Circulation of Intelligence', in Diplomacy and Early Modern Culture, ed. Robyn Adams and Rosanna Cox (Basingstoke: Palgrave, 2011), pp. 63-81. 
due to his father's debts and loss of familial lands during Mary l's reign. Letters survive from 1573-4 that see him petitioning Lord Burghley, his uncle through Burghley's first marriage, for governmental office, and in 1575 he was made a clerk of the Privy Council. ${ }^{48}$ For the first years of the clerkship at least this position seems to have been a sinecure, granted by Burghley in response to Cheke's financial problems. ${ }^{49}$ Unlike all the other clerks, both at this time and throughout Elizabeth's reign, Cheke had no previous experience in government office and had not travelled abroad; his family connections, Jacqueline Vaughan argues, meant that he "was virtually guaranteed an office at court, regardless of his ability" ${ }^{50}$ However, this lack of experience, European languages and training could not hold for long, and he spent the next three years touring Italy and France. I would suggest that this foreign travel was specifically intended to develop Cheke personally for the government positions he sought (and had attained in name), through both training in foreign languages and in the gathering and transmission of information, rather than being an official diplomatic commission as part of his clerkly duties. ${ }^{51}$

This training can be traced in the extant letters sent to Burghley during his travel. ${ }^{52}$ Dated 24 October 1576, a lengthy letter from Cheke in Genoa reflects Burghley's (as yet unfulfilled) expectation of advertisements, and explains why thus far he has had little to offer. ${ }^{53} \mathrm{He}$ apologises that he has not "learned any good intelligence" and states that the reasons for this were his being persuaded to travel a particular route, and a lack of languages (especially French) that has hindered his access to information. ${ }^{54} \mathrm{He}$ has learned the hard way that few locals were able to converse with him in Latin, meaning that "Such knowledg as I have gotten in travayle, I have atcheeved ether by mine eye, or by discretion". ${ }^{55}$ In excusatory style, Cheke recounts that by this time he has been threatened and his servant arrested, his travelling companion has

48 John Roche Dasent, ed., Acts of the Privy Council 1575-77, vol. 9 (London: HMso, 1894), p. 166. He is sworn in on 19 July 1575 , along with Thomas Wilkes.

49 Jacqueline Vaughan refers to Cheke's appointment as "a reward or gift" and expresses surprise at his lack of qualifications: 'Secretaries, Statesmen, and Spies: The Clerks of the Tudor Privy Council, c.1540—c.1603', PhD thesis (University of St. Andrews, 2006), esp. pp. $36-7,48$.

5o Vaughan, 'Secretaries, Statesmen', p. 36.

51 For the relationship of diplomatic work overseas with the clerkship, see Williamson, 'Before "Diplomacy"', pp. 101-5.

52 A sample of these letters is provided in Williamson, 'Before "Diplomacy"', appendix two.

5324 October 1576, Cheke to Burghley, BL Lansdowne MS 23, fos. 186r-7r.

54 Lansdowne Ms 23, fo. $186 \mathrm{r}$.

55 Lansdowne MS 23, fo. 186 r. 
abandoned him, and he has seen his letters "opened \& redd before $\mathrm{o}^{\mathrm{r}}$ faces". 56 What he does convey is his own travel experience, rumours of discontented marauders, and details of the plague (where it is bad, numbers of dead, difficulties for travellers). Despite this information, he states that the only real "newes" he can offer is that the emperor Maximilian II has recently died, but he accepts that this will be common knowledge by the time his letter reaches Burghley (his letter is dated twelve days after the emperor's death). ${ }^{57}$ The next surviving letter shows a notable improvement: it contains points of political news and significantly is written in Italian, boasting in content and form that Cheke has been using his travel to good effect. ${ }^{58}$ By his letter of 19 August 1577, Cheke is evidently in frequent contact with Burghley (he refers to a previous letter), and offers substantial news, which is the primary purpose of this brief and direct missive. ${ }^{59} \mathrm{He}$ writes of the "bruit come $\mathrm{w}^{\text {th }}$ in thes 3 dayes to Paris, and advertised out of $y^{\mathrm{e}}$ low countries to $\mathrm{o}^{\mathrm{r}}$ Englishmen here" that the Queen of Scots had been executed, of rumours concerning the English ambassador in Paris, and of the activities and possible motives of the Duke of Guise. ${ }^{60}$ He is back in France by May 1578, again writing to Burghley and mentioning, perhaps not inconsequentially, his lack of money. ${ }^{61}$ He has clearly become a valuable source of information, and importantly a trained and trusted loyal civilian: in October of that year, he carries letters home from the resident ambassador Sir Amias Paulet. This is an important commission from an important diplomatic figure that could lead to personal interviews with the highest political circles back in England. ${ }^{62}$ Three months following this, Cheke was called to the Privy Council to sign up to a rota spreading the work of the clerkship evenly amongst the clerks of the council. ${ }^{63}$ It would seem that the other clerks wanted him, now that he had

56 Lansdowne Ms 23, fo. 186r.

57 Lansdowne Ms 23, fo. 186v.

5823 January $1576 / 7$, Lansdowne MS 24, fos. 58 r-9v.

5919 August 1577, Cheke to Burghley, TNA, SP 78/1, fos. 21r-2v.

6o SP 78/1, fo. 21r. For a transcription, see Williamson, 'Before "Diplomacy”, Appendix 2.2.

6120 May 1578, Cheke to Burghley, TNA, SP 15/25, fos. 177r-8v.

62 Consider the example of legation secretary and later ambassador Thomas Edmondes bearing letters for Henry Unton, in which he is praised and recommended. Edmondes returned to France, arriving on 24 March 1592, with letters that reference personal interview from Lord Chamberlain Hunsdon, Lord Admiral Charles Howard, Vice Chamberlain Thomas Heneage, Robert Devereux and Robert Cecil, who writes "this bearer can certifie you of all or occurrents", BL Add. Ms 38137 , fos. $137 \mathrm{r}-8 \mathrm{v}$.

63 Dasent, ed., Acts of the Privy Council 1578-8o, 9: 4-5: "3 Januarij, 1578 [Ns 1579] The same daye, Mr Henry Cheek, heretofore sworn one of the Clerkes of her Majesties most 
enjoyed similar training to that they had gained in their youth, to fulfil the duties of the position as well as benefitting from its perks.

There is another important point to make here: that travellers do not just transmit news back home independently but can also be an unofficial part of an existing embassy, often used to bear messages and deliver post, and could be used to source news and intelligence for the ambassador. Palmer instructs the traveller to "make oft repaire to the Ambassadour of his Prince (in case there remaine any there) advertising him of such importances as shall chaunce unto him in that Countrey". ${ }^{64}$ If avoiding stepping on the ambassador's toes is a concern, then it follows that the news-gathering activity of the traveller can be related to that of the diplomat. We have seen that during his time in France, Cheke is connected to the ambassador in Paris: he reports on rumours circulating about him, and is employed by him to bear letters-this association makes it not unlikely that he was involved in other tasks.

Travel gave a useful freedom of movement to Anthony Bacon, brother to Francis and later close associate of the earl of Essex, who provides an example of a traveller who is directly called upon by the resident ambassador to involve himself in secret diplomatic and intelligencing activity. Bacon travelled throughout the 1580 in France and Geneva, and can be seen following the ideals of the ars apodemica: he writes a discourse entitled 'Notes on the present state of Christendom', and forwards information on the politics of many European countries to Burghley through his friend Nicholas Faunt, secretary to Walsingham. ${ }^{65}$ However, this scholarly information-gathering veered into

honourable Privey Counsell, being retorned home out of the partes of beyond the seas, appon an agreement and order taken by Edmond Tremayn, Robert Beale, Thomas Wilkes and the said Henry Cheeke among them selves for the time and terms of their severall waitinges as is conteyned in the note folowing, the same note was exhibited and shewed unto the Lords then present, and being by them liked of and allowed, it was by their Lordships ordered that the same shold be entred into the Counsell Booke, there to remain of record and be observed by them accordingly". That Cheke surrendered the office of the clerkship less than two years later (again unusual in a post often held for decades) suggests that this was never a role he was particularly interested in; he instead joined the Council of the North as secretary in 1581, where he was also made JP for an extraordinary five counties, see Vaughan, 'Secretaries, Statesmen', pp. 66, 119.

64 Palmer, The Travailer, p. 128.

65 See David Potter, Foreign Intelligence and Information in Elizabethan England: Two English Treatises on the State of France, 1580-1584 (Cambridge: Cambridge University Press, 2004), p. 7. He may also be involved in transferring money to diplomats abroad, as suggested by a letter from Anthony Bacon to Francis Bacon on paying Master Bodley "by one warrant 
activity that was both more secretive and more involved with the English diplomatic presence abroad. In May 1584, ambassador Edward Stafford wrote to Walsingham to suggest that Bacon be used to reassure Henri of Navarre of the Queen's continued but somewhat covert friendship, and this "under couller of traveling the Countrye ... $\mathrm{w}^{\text {th }}$ out being knowen".66 Stafford asserts that "in my opinion yf her $\mathrm{Ma}^{\text {tie }}$ doe determyne to do ytt there is none properer for that pourpose, then Master [cipher] ${ }^{\wedge \text { Bacon } \wedge}$ being there allredie $\mathrm{w}^{\text {th }}$ littell charge or none, onlie of the sending of her mates letters to him ... "67 This illustrates that Bacon and his whereabouts are already known to the ambassador. The sense is that as a traveller he is available to the embassy and the crown, free to deliver letters or gather information, as implied by the off-hand differentiation between 'littell charge or none'; this activity is liminal insofar as it is not officially commissioned or instructed. The covert nature of this arrangement is underscored by Stafford's use of cipher for Bacon's name. ${ }^{68}$ Bacon here begins to bridge the gap between the traveller for education who conveys useful news home and someone who is employed more directly-following this arrangement he will cease to be engaged in neutral travel and will rather be "under couller of traveling".

Bacon himself manifests everything that parents and patrons feared of travel, and also demonstrates its benefits. His mother, Anne Bacon, was vocally angry over Bacon's lack of contact and refusal to return to England. Walsingham chided him over his extensive use of self-medication or "physic". At times he fought accusation that his lodging was a nest for 'rebellious Huguenots', and during his stay at Henri of Navarre's court at Montauban he got in trouble for debt and was arrested for sodomy. Charges of sexual immorality, drugs, debt and religious extremism are all levied at Bacon during his time abroad, yet the flexibility that accompanied relatively unencumbered travel meant that Bacon was able to deliver information, please patrons, and form a network of

by a bill of exchange to Lyons $£ 1554 \mathrm{~S} 2 \mathrm{~d}$ ". However, the letter is not dated so the context remains unclear. See Lisa Jardine and Alan Stewart, Hostage to Fortune: The Troubled Life of Francis Bacon (London: Victor Gollancz, 1998), p. 84.

66 Stafford to Walsingham, 2 May 1584, TNA, SP 78/11, fo. 86v. Stafford's embassy has been the subject of much critical debate, with some suggestion that he acted as a double-agent as a way of paying his gambling debts. See Mitchell Leimon and Geoffrey Parker, "Treason and Plot in Elizabethan Diplomacy: The "Fame of Sir Edward Stafford" Reconsidered, English Historical Review, 111 [444] (1996), pp. 1134-58.

67 TNA, SP $78 / 11$, fo. $86 \mathrm{v}$.

68 A later hand adds "Bacon" as a supralinear annotation. On Bacon's activity as an un- or semi-official diplomatic agent in this mission, see Williamson, 'Before “Diplomacy”, p. 116. 
contacts that would serve him very well when he did eventually return to England. Travel allowed him to rub shoulders with people such as Théodore Beza and Michel de Montaigne, and, once he was introduced into Essex's circle, helped him to build the intelligence network that supported Essex in his bid to become a leading statesman:

Anthony Bacon soon enhanced Essex's remarkable secretariat by coordinating (unpaid) a massive foreign intelligence operation with contacts across Europe, including Thomas Bodley, Sir Thomas Chaloner, Dr Henry Hawkins, John Napier, Sir Anthony Sherley, and [Anthony] Standen. A good quantity of his correspondence is extant at Lambeth Palace Library and formed the basis of Thomas Birch's once standard history of Elizabeth's reign. ${ }^{69}$

I have argued here that travellers were part of the system by which international political information was gathered and conveyed, and that educational travel could blur into diplomatic business. Further, the motivation for this was often to advance a traveller's career within this system (loosely-conceived), with travel and reportage being essential training for higher-status positions in diplomatic and governmental spheres. The aim is not to conclude that all travellers were asked to be spies or newsmongers, but that one of the reasons for the constant repetition of the importance of observation for the good of the common weal was that this activity can be one way for those in governing circles (or out of them) to inform themselves of the happenings in Europe. The pamphlets of travel advice and letters of scholarly counsel, as well as being a literary tradition enjoyed for its academic value or intended to encourage learning for one's own self, can be read as instructions for gathering information, as a corollary to the official instructions of ambassadors and negotiators. Since this activity is several things at once, namely travel for experience, travel for personal knowledge, travel for information, and travel for career development, it depends on the individual travellers as to where they place themselves and what, if any, news they gather in their time abroad.

The above examples are certainly not equivalent or uniform: they display the variety of people who followed this model of educative travel and crown service, and the different ways they made use of it. One could even suggest that it is the travel advice genre itself that does the real fishing for news, with authors and senders encouraging their clients to make use of their privileged

69 Alan Stewart, 'Bacon, Anthony (1558-1601)', ODNB < www.oxforddnb.com/view/article/988> [29/06/14]. 
access. This frames the travellers themselves as the bait, speculatively cast to catch news in dangerous waters. However, just as much as the leading elite would not want all and sundry sending them their travel woes, neither would they want their own sons and relations putting themselves in real reputational or physical danger. Perhaps there is a twin audience here, then: the addressed nobleman who is urged to source information but to do so safely, and the wider ranks among whom the request percolated, who could take greater risks, perhaps thereby making their way in the world. As with most things, this comes down to a distinction of status and intention. For those whose position (social, geographical and political) allowed them, delivering information and news was both an expectation and an opportunity; what use they made of this was down to them. 